\title{
Drug-induced hemichorea
}

\author{
Takashi Watari, ${ }^{1}$ Yasuharu Tokuda ${ }^{2}$
}

'Department of General Internal Medicine, Tokyo Joto Hospital, Koutou-ku, Japan ${ }^{2}$ Japan Community Healthcare Organization, Tokyo, Japan

\section{Correspondence to}

Professor Yasuharu Tokuda, yasuharu.tokuda@gmail.com

Accepted 9 February 2015
CrossMark

To cite: Watari T, Tokuda Y. BMJ Case Rep Published online: [please include Day Month Year] doi:10.1136/ bcr-2014-208872

\section{DESCRIPTION}

A 92-year-old Japanese woman presented with an 8-day history of involuntary movements of the right-sided unilateral upper and lower extremities. In her medical history, the patient had only mild hypertension but no significant disorders involving central, peripheral or autonomic nervous systems. None of her family members had hereditary neurological diseases. While being interviewed about her drug history, the patient reported that she had orally taken zolpidem $(10 \mathrm{mg} /$ day $)$ and zopiclone $(7.5 \mathrm{mg} /$ day) every night for the last 2 weeks, which her primary care physician had prescribed for a sleeping disturbance. On physical examination, there was intractable right-sided unilateral hemichorea (video 1). The rest of the neurological and physical examinations were unremarkable.

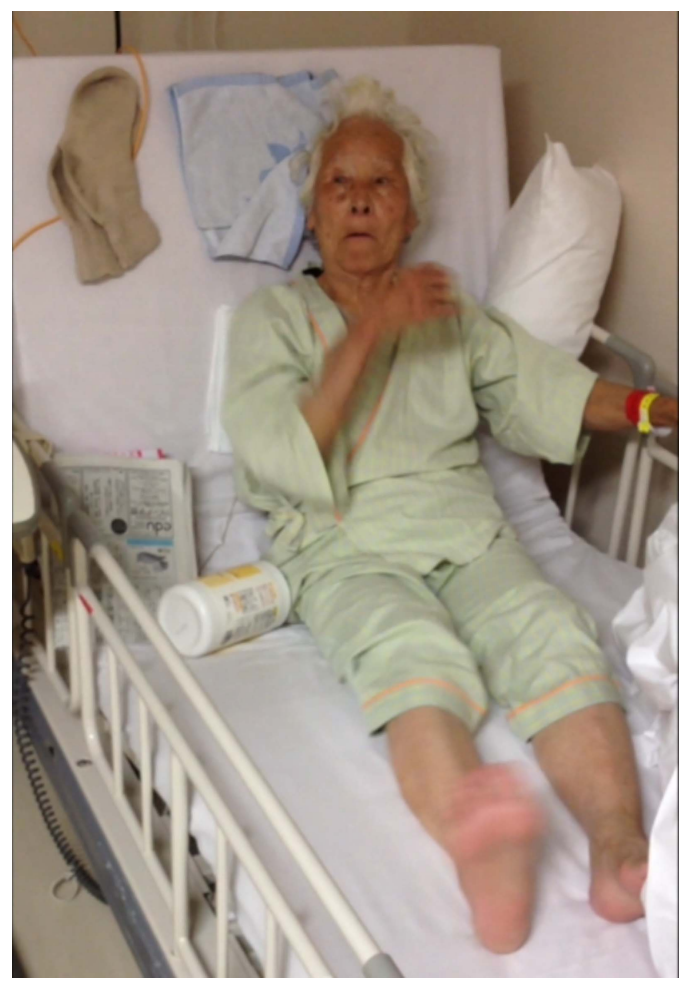

Video 1 The patient with hemichorea.
Imaging and laboratory studies were all within normal limits, including complete blood count, blood chemistry, thyroid function and cerebrospinal fluid examination, brain CT scan, MRI and EEG. Based on a diagnosis of drug-induced hemichorea, zolpidem and zopiclone were discontinued and the patient received tiapride for a few days. After discontinuation of the sleeping medications, the involuntary movements gradually disappeared over several days. Chorea or hemichorea can be caused by dysfunction of the basal ganglia due to organic neurological lesions or medications acting on the central nervous system. ${ }^{12}$ We report our patient as a rare case with hemichorea probably caused by non-benzodiazepine sedatives. ${ }^{3}$ This case may be of relevance to primary care physicians, since this class of medication has become popular because of its reputation for relatively safe profiles.

\section{Learning points}

- Careful description is mandatory for accurate classification of involuntary movement.

- Chorea or hemichorea can be caused by medications acting on the central nervous system.

- Popular non-benzodiazepine sedatives could lead to drug-induced chorea or hemichorea.

Contributors TW took care of the patient, and TW and YT wrote the manuscript.

Competing interests None.

Patient consent Obtained.

Provenance and peer review Not commissioned; externally peer reviewed.

\section{REFERENCES}

1 Piccolo I, Defanti CA, Soliveri $P$, et al. Cause and course in a series of patients with sporadic chorea. J Neurol 2003;250:429-35.

2 Ghika-Schmid F, Ghika J, Regli F, et al. Hyperkinetic movement disorders during and after acute stroke: the Lausanne Stroke Registry. J Neurol Sci 1997;146:109-16.

3 Jain KK, Bradley WG. Drug-induced movement disorders. Drug induced neurological disorders. Seattle: Hogrefe \& Huber, 2001:171-209 


\section{Images in...}

Copyright 2015 BMJ Publishing Group. All rights reserved. For permission to reuse any of this content visit http://group.bmj.com/group/rights-licensing/permissions.

BMJ Case Report Fellows may re-use this article for personal use and teaching without any further permission.

Become a Fellow of BMJ Case Reports today and you can:

- Submit as many cases as you like

- Enjoy fast sympathetic peer review and rapid publication of accepted articles

- Access all the published articles

- Re-use any of the published material for personal use and teaching without further permission

For information on Institutional Fellowships contact consortiasales@bmjgroup.com

Visit casereports.bmj.com for more articles like this and to become a Fellow 